\title{
Establishment in vitro shoots and callus Dahlia sp. for later use to obtained inulin
}

\section{Establecimiento in vitro de brotes y callos de Dahlia sp. para su posterior uso en la obtención de inulina}

Margarita Ivonne Garrido-Gutiérrez*, Miriam Gabriela Pérez-Delfín, Sergio ZavalaCastillo

Unidad Profesional Interdisciplinaria de Ingeniería campus Zacatecas del Instituto Politécnico Nacional, Departamento de Formación Específica, Programa Académico de Ingeniería en Alimentos, Zacatecas, Zac. México.

*Corresponding author.

E-mail address: maguigarrido@yahoo.com (M. I. Garrido-Gutiérrez).

Article history:

Received: 1 January 2017 / Received in revised form: 25 May 2017 / Accepted: 19 June 2017 / Published online: 1 July 2017

https://doi.org/10.29267/mxjb.2017.2.2.130

\begin{abstract}
In order to have an efficient protocol and to be able to produce inulin in the future, experimental conditions were established to obtain artificial cultures of Dahlia sp. plant lines A1, A2, P1, P2 and ENN to obtain shoots, calli, cell and root suspension cultures with different combinations of plant growth regulators and environmental conditions. The explants used were axillary buds. With these, shoots and whole plants were obtained in all lines. The P1 line was the fastest, needed 7 days of incubation to respond to MS medium without plant growth regulators. Calli were obtained with stem explants after 10 days with $0.5 \mathrm{mg} / \mathrm{L}$ benzylaminopurine (BAP) and $1 \mathrm{mg} / \mathrm{L}$ indoleacetic acid (IAA). Calli suspension cultures were achieved with stirring at $88 \mathrm{rpm}$ and the same plant growth regulators combinations that were obtained for calli formation. Tuberization induction and root formation were with $5 \mathrm{mg} / \mathrm{L}$ BAP, $0.5 \mathrm{mg} / \mathrm{L}$ IAA, $80 \mathrm{~g} / \mathrm{L}$ sucrose and $0.2 \mathrm{mg} / \mathrm{L}$ BAP plus $60 \mathrm{~g} / \mathrm{L}$ sucrose, respectively. The response time and the quality of buds, calli and roots obtained from Dalhia sp. showed favorable experimental conditions to initiate the experiments for the stimulation of inulin production.
\end{abstract}

Keywords: Buds, callus, culture in vitro, Dahlia, inulin, production

\section{RESUMEN}

Para contar con un protocolo eficiente y poder producir inulina en un futuro, se establecieron las condiciones experimentales para obtener cultivos artificiales de las líneas 
vegetales de Dahlia sp. A1, A2, P1, P2 y ENN con el objetivo de obtener brotes, callos, cultivos de células y raíces en suspensión con diferentes combinaciones de reguladores de crecimiento vegetal y condiciones ambientales. Los explantes usados fueron yemas axilares. Con éstos se obtuvieron brotes y plantas completas en todas las líneas. La línea P1 fue la más rápida, necesitó de 7 días de incubación para responder al medio MS sin reguladores de crecimiento vegetal. Los callos se obtuvieron con explantes de tallos después de 10 días con $0.5 \mathrm{mg} / \mathrm{L}$ de bencilaminopurina (BAP) y $1 \mathrm{mg} / \mathrm{L}$ de ácido indolacético (AIA). Los cultivos en suspensión de callos se lograron con la agitación a 88 rpm y las mismas combinaciones de reguladores del crecimiento de las plantas que se obtuvieron para la formación del callo. La inducción de tuberización y formación de raíces fueron con $5 \mathrm{mg} / \mathrm{L}$ de BAP, $0.5 \mathrm{mg} / \mathrm{L}$ de AIA, $80 \mathrm{~g} / \mathrm{L}$ sacarosa y $0.2 \mathrm{mg} / \mathrm{L}$ BAP más $60 \mathrm{~g} / \mathrm{L}$ sacarosa, respectivamente. El tiempo de respuesta y la calidad de los brotes, callos y raíces que obtuvimos de Dalhia sp. mostraron condiciones experimentales favorables para iniciar los experimentos para la estimulación de inulina.

Palabras clave: Brotes, callos, cultivo in vitro, Dahlia, inulina, producción

\section{INTRODUCTION}

Dahlia is the Mexican national flower from where it is a native plant (Mera Ovando \& Bye Boettler, 2006). Dahlia tuberous roots store inulin, which is a poorly assimilated carbohydrate so it provides poor caloric yield, does not contribute to increase body weight, nor to raise blood glucose levels in humans (Badui, 2013). Recently, inulin is used to make functional foods, such as honey or agave inulin in commercial presentations. Dahlia plants are grown in our country as an ornamental flowers, which are exported (Mera Ovando \& Bye Boettler, 2006) (Mera Ovando \& Bye Boettler, 2006). There are no records of their use to exploit it as an inulin source. However, the agronomic practices necessary for the production of tuberous roots as dry matter have been reported (Arenas et al., 2011). And there are research available for the plant micropropagation (Hernández Pérez \& Mejia Muñoz, 1994) but not for obtaining inulin. Therefore it is necessary to establish an in vitro culture of the plant Dahlia to know its potential for inulin production. The objective of this work was to establish the experimental conditions to obtain artificial cultures of several lines of Dahlia sp. which will allow the further development of all research.

\section{MATERIALS AND METHODS}

\subsection{Plant lines}

Five plant lines of the genus Dahlia were used named A1, A2, P1, P2 and ENN. All planted on the ground. The first four were donated by Q.F.B. Karen Paola Mejía Márquez (UPIIZIPN) and the ENN was acquired in a nursery in the state of Zacatecas. They were acclimated under greenhouse conditions for two months prior to the beginning of the in 
vitro cultures in commercial substrate with bacterial load diminished by pasteurization and placed in pots of $24 \mathrm{~cm}$ in diameter. Seeds of lines A1, A2, P1 and P2 were used for germination tests.

\subsection{Disinfection of plant tissues and obtaining explants}

Plant branches about $8 \mathrm{~cm}$ long, with axillary buds and internodes, were washed twice with commercial liquid detergent and tap water. They were then immersed in a $70 \%(\mathrm{v} / \mathrm{v})$ ethanol solution for 1 min under gentle shaking. The tissues were then placed in a solution of 5\% (v/v) sodium hypochlorite (commercial chlorine) with a drop of commercial liquid detergent for $15 \mathrm{~min}$ in light and continuous stirring. Finally, they were rinsed four times with sterile distilled water. The explants were obtained by dissection of the treated tissues to obtain axillary buds with internodes of approximately $1.0 \mathrm{~cm}$, stems of $1 \mathrm{~cm}$ long from the proximal parts of the branch and fragments of immature leaves of approximately $1 \mathrm{~cm}^{2}$. Dahlia seeds were imbibed overnight in tap water and $10 \%$ sucrose (w/v) before applying disinfection treatment similar to that described above. The difference was that three washes were made with detergent and running water, in addition, the immersion in sodium hypochlorite solution was for $20 \mathrm{~min}$ at a concentration of $30 \%(\mathrm{v} / \mathrm{v})$.

\subsection{Culture medium and sowing conditions}

The complete salts of Murashige and Skoog medium (MS, Murashige and Skoog, 1962; SIGMA-ALDRICH, St. Louis, CO, USA) were used supplemented with $100 \mathrm{mg} / \mathrm{L}$ myoinositol, $2 \mathrm{mg} / \mathrm{L}$ glycine, $0.5 \mathrm{mg} / \mathrm{L}$ nicotinic acid, $0.5 \mathrm{mg} / \mathrm{L}$ pyridoxine, $0.1 \mathrm{mg} / \mathrm{L}$ thiamine, $30 \mathrm{~g} / \mathrm{L}$ sucrose and different combinations of plant growth regulators (see results), 1 or 2 $\mathrm{g} / \mathrm{L}$ phytagel and $\mathrm{pH}$ was adjusted to 5.6. For the seeds the same medium was used without plant growth regulators. For the suspension cultures, the culture medium was used with of plant growth regulators combinations which calli were obtained, but without phytagel. The incubation was at $25{ }^{\circ} \mathrm{C} \pm 2{ }^{\circ} \mathrm{C}$, with 1560 lumens and $16 \mathrm{~h}$ light $/ 8 \mathrm{~h}$ dark.

\subsection{Induction of shoots and calli}

To obtain shoots of Dahlia sp. axillary buds were used as explants and also seeds of all plant lines. These were cultivated in MS medium with the complete salts without plant growth regulators. The stems and leaves of dahlia plants obtained in vitro were used as explants to generate calli. Combinations of growth regulators (Skoog et al., 1965) were shown in Table 2 of the results.

\subsection{Treatments for tuberization and roots cultured}

From the roots of complete plant Dahlia sp. under in vitro conditions of two weeks incubation, explants of approximately $2 \mathrm{~cm}$ were obtained. It were placed in MS medium with their organic part and the plant growth regulators proposed by Anjum \& Villers (1997). Briefly, treatment A consisted of $5 \mathrm{mg} / \mathrm{L}$ BAP, $0.5 \mathrm{mg} / \mathrm{L}$ AIA and $80 \mathrm{~g} / \mathrm{L}$ sucrose. Treatment B with $5 \mathrm{mg} / \mathrm{L}$ BAP and $80 \mathrm{~g} / \mathrm{L}$ sucrose and C was formulated with only $80 \mathrm{~g} / \mathrm{L}$ sucrose. To the three treatments were added $2 \mathrm{~g} / \mathrm{L}$ phytagel. Two lighting conditions were 
tested, $8 \mathrm{~h}$ light/16 $\mathrm{h}$ dark and total darkness. The treatments for cultured root were 0.1 $\mathrm{mg} / \mathrm{L}$ IAA and $30 \mathrm{~g} / \mathrm{L}$ sucrose (RA), $30 \mathrm{~g} / \mathrm{L}$ sucrose (RB) and $0.2 \mathrm{mg} / \mathrm{L}$ BAP and $60 \mathrm{~g} / \mathrm{L}$ sucrose (RC). An explant was considered as a unit of experimentation in all the tests presented.

\subsection{Histological study}

Histological analysis was made of callus cultures and cells suspension at different incubation times, freshly prepared in distilled water. For the study of the roots, photographs were taken throughout their incubation, with a Sony Cyber shot digital camera of 7.2 megapixels, with optical zoom of 3X, model DSC-W80. To analyze cell and root morphology Motic DMBA-310 optic microscopy and the Motic Plus 2.0 ML imaging software (Motic China Group Co., Ltd.) were used.

\section{RESULTS}

The disinfection processes which $0 \%$ of contamination was obtained using the five Dahlia sp. plant lines and seeds were described in methodology. Shoots were obtained from axillary buds as explants in MS medium without plant growth regulators (Table 1), on average after 4 days of incubation. In the A1 plant line shoots were obtained at 2 days of incubation, but root formation was slow, after 8 to 10 days. The A2 line presented a behavior similar to A1 in relation to formation of its root system. With P1 (Fig. 1A) as soon as they were cultivated their root system was developed (Fig. 1B), on average at 3 days of incubation. P2 developed root after 5 to 7 days. The axillary bud grew from its aerial part on average one axillary bud every 4 days, so that the number of plants can be doubled in a maximum of 15 days.

Table 1. Number of complete plants of different Dahlia sp. plant lines obtained by in vitro culture after two months of incubation.

\begin{tabular}{llllll}
\hline $\begin{array}{l}\text { Plant } \\
\text { line }\end{array}$ & A1 & A2 & P1 & P2 & ENN \\
\hline $\begin{array}{l}\text { Number of } \\
\text { seedlings }\end{array}$ & 4 & 3 & 23 & 1 & 0 \\
\hline
\end{tabular}



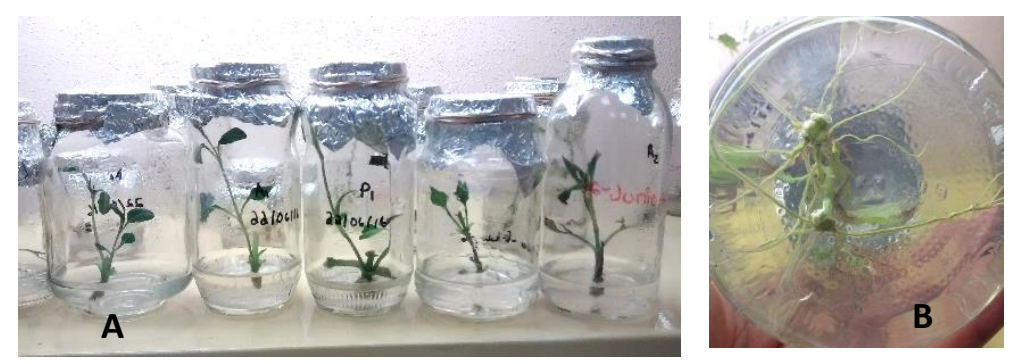

Fig. 1. Plants of Dahlia sp. obtained in vitro after 4 days of incubation. A: A1, A2 and P1 plant lines. B: Root system of P1 line.

It was evident that with P1 line more plants were obtained in vitro per unit time (Table 1). In addition, with this line and A2, conspicuous cell proliferation as a callus in the cut zone was observed (Fig. 2A). For this reason, these plant lines were used to calli induction with plant growth regulators treatments (see below). On the other hand, the root system that developed P1 and A2 was qualitatively thicker than the rest of the other lines, which made them also excellent candidates for tuberization and root culture studies. ENN presented systemic contamination and the shoots obtained from it were contaminated profusely during the subcultures until the line was lost. Seeds did not germinate under in vitro or ex vitro culture conditions (data not shown). Callus was produced with the combination of plant growth regulators $0.5 \mathrm{mg} / \mathrm{L}$ BAP and $1 \mathrm{mg} / \mathrm{L}$ IAA, after 10 days using stems as explants (Table 2). Although with leaves were also obtained calli (Fig. 2B), these were nondisintegrable. This treatment was fastest. The concentration of phytagel that favored callus cultures was $1 \mathrm{~g} / \mathrm{L}$. With the combination of $1 \mathrm{mg} / \mathrm{L}$ BAP and $1 \mathrm{mg} / \mathrm{L} 2,4$ dichlorophenoxyacetic acid (2,4-D) there was no response in the explants, but they oxidized rapidly, on average 5 days. When a combination of $1 \mathrm{mg} / \mathrm{L}$ BAP and $0.5 \mathrm{mg} / \mathrm{L}$ IAA was used no oxidation was observed and 20 days later the formation of undifferentiated cell masses was evident.

Table 2. Response obtained with Dahlia plant lines and different combinations of plant growth regulators.

\begin{tabular}{|c|c|c|c|c|}
\hline \multirow{2}{*}{$\begin{array}{l}\text { Plant } \\
\text { linea }\end{array}$} & \multicolumn{4}{|c|}{ Combinations of plant growth regulators } \\
\hline & $\begin{array}{l}1 \mathrm{mg} / \mathrm{L} \mathrm{2,4-D} \\
1 \mathrm{mg} / \mathrm{L} \text { BAP }\end{array}$ & $\begin{array}{c}0.5 \mathrm{mg} / \mathrm{L} \text { AIA } \\
1 \mathrm{mg} / \mathrm{L} \text { BAP }\end{array}$ & $\begin{array}{c}0.5 \mathrm{mg} / \mathrm{L} \text { BAP } \\
1 \mathrm{mg} / \mathrm{L} \text { AIA }\end{array}$ & $\begin{array}{l}\text { Without } \\
\text { RCV }^{++}\end{array}$ \\
\hline A1 & SR* & $\mathrm{NE}^{+}$ & NE & Plant with root \\
\hline A2 & SR & $\mathrm{NE}$ & $\mathrm{CD}^{* * * *}$ & Plant with root \\
\hline P1 & SR & CND** & $\mathrm{CD}^{* * *}$ & Plant with root \\
\hline P2 & SR & $\mathrm{NE}$ & $\mathrm{NE}$ & Plant with root \\
\hline ENN & SR & $\mathrm{NE}$ & $\mathrm{NE}$ & Plant without root \\
\hline
\end{tabular}

$* \mathrm{SR}=$ unanswered $; * * \mathrm{CND}=$ callus no friable; $* * * \mathrm{CD}=$ callus friable $; \mathrm{NE}^{+}=$not yet evaluated; $\mathrm{RCV}^{++}=$plant growth regulators. 

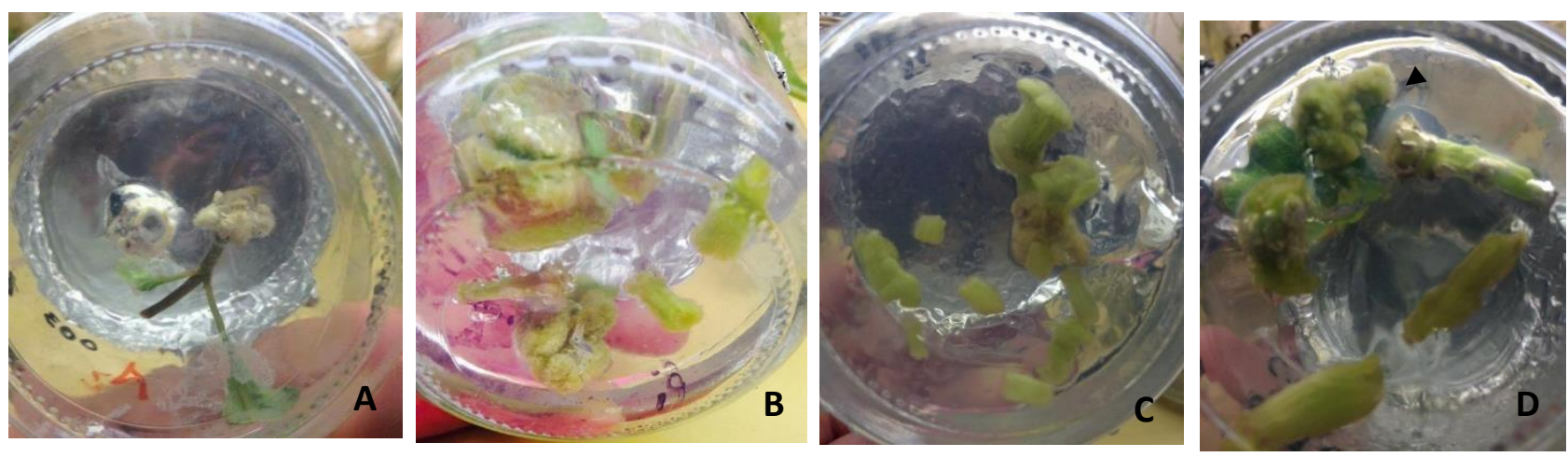

Fig. 2. Callus obtained in $\mathrm{A} 2$ and $\mathrm{P} 1$ plant lines after 15 days of incubation. A: callus obtained in the cut zone of A2 in medium without growth regulators. B and $\mathbf{C}$ : callus of line P1 of stem as explant. D: callus obtained from leaf explants of P1 (arrowhead) and stems.

Callus suspension cultures obtained were started after 4 weeks of induction in semisolid medium. Although leaf explants had a faster response to callus formation (Fig. 2D) compared to stem explants (Figs. 2B and 2C), they were unviable to obtain cells suspension. Leaves explants with callus subcultivated to liquid medium with stirring were oxidized in a short time, from 4 to 5 days approximately, being even faster the oxidation in those explants that were not exposed directly to the light source. For that reason the explants suitable to obtain callus were the stems. After 10 days of incubation and a shaking of $110 \mathrm{rpm}$, complete calli oxidation of occurred (Fig. 3A) and few cells were observed in the liquid medium and lysis in cells greater than $5 \mu \mathrm{m}$ (Fig. 4A) and $7.2 \mu \mathrm{m}$ elongated (Fig. 4B), appeared it did not occur in $1 \mu \mathrm{m}$ round cells (Fig. 4A). Therefore it was decided to decrease the agitation at $88 \mathrm{rpm}$ and it was possible to eliminate the oxidation of calli (Figs. 3B and 3C). Also, a dependence of the agitation and illumination conditions was found to get callus and the cells suspension without oxidation, since when the calli were incubated without agitation they were oxidized in approximately 4 days. The same happened when the light intensity was less than 1560 lumens. After 45 days of incubation, detachment of callus nodules formed on the explants in calli suspension cultures was evident (Fig. 3D).This cellular detachment of calli was presented shortly after suspension cultures started (Fig. 3B). 

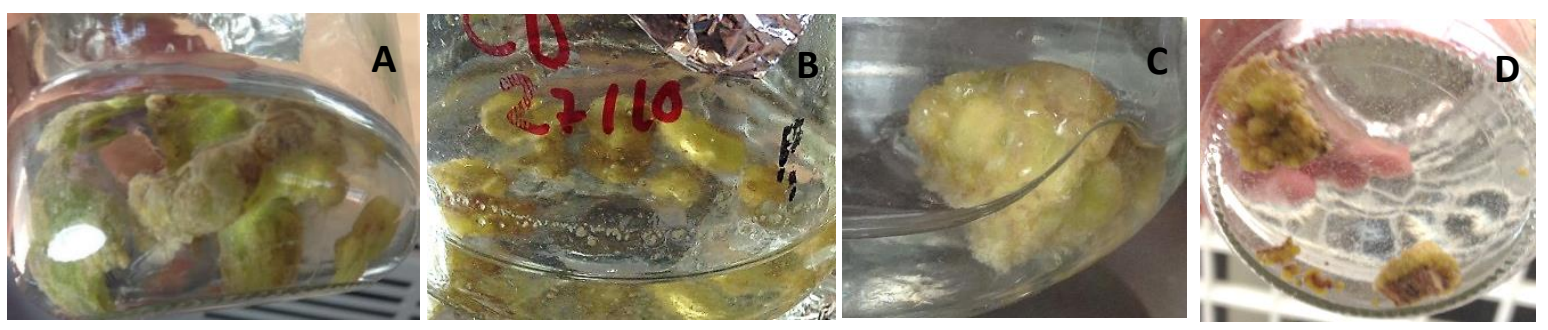

Fig. 3. Callus suspension culture of $\mathrm{P} 1$ plant line. A: after 3 days of incubation at $110 \mathrm{rpm}$. B: after 4 days of incubation at $88 \mathrm{rpm}$. C: close up of B. D: after 42 days of incubation.
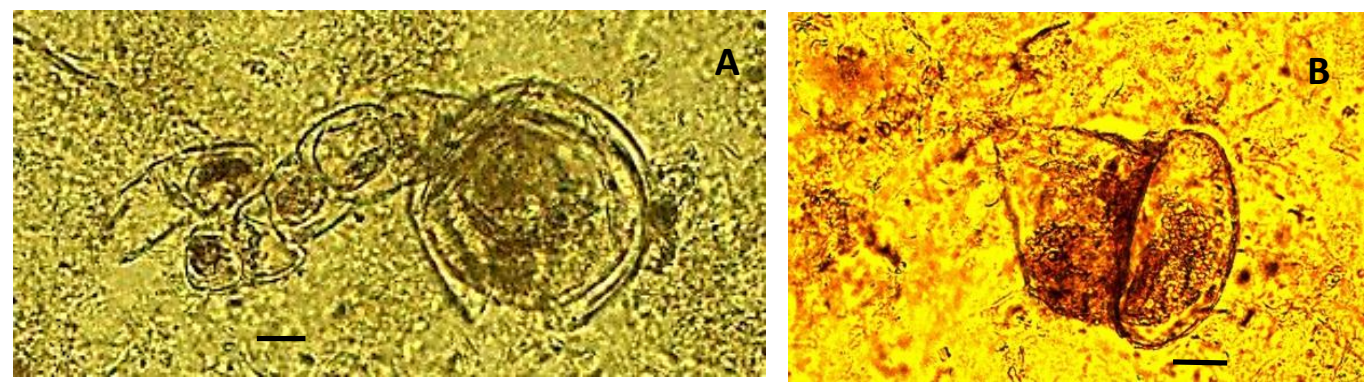

Fig. 4. Dahlia cells from P1 line after 10 days of incubation at $110 \mathrm{rpm}$. Cell lysis is observed. A: $1 \mu \mathrm{m}$ scale bar. B: $2 \mu \mathrm{m}$ scale bar.

In relation to the experiments to promote tuberization, treatments $\mathrm{A}$ and $\mathrm{B}$ in 8 hours light/16 h dark showed root thickening, in addition new root shoots were generated (Table 3 ). In treatment $A$ there was a difference in size of root thickness of $13.1 \mu \pm 5,406$ in 10 days of incubation. These results were not observed with treatment $\mathrm{C}$ since there was no root growth or thickening, only shoot growth was observed (Table 3). In roots subcultivated in medium A and darkness showed thickening, aerial part growth without green coloration and few new roots. Roots subcultivated in $\mathrm{C}$ medium did not present any changes, even the roots were oxidized and there was no evident growth of the aerial part. For treatment $\mathrm{C}$ no root thickening is observed, but there is root formation and, like treatment $\mathrm{B}$, there is no shoot growth (Table 3 ). 
Table 3. Results of tuberization in P1 plant line. Proven lighting conditions are shown.

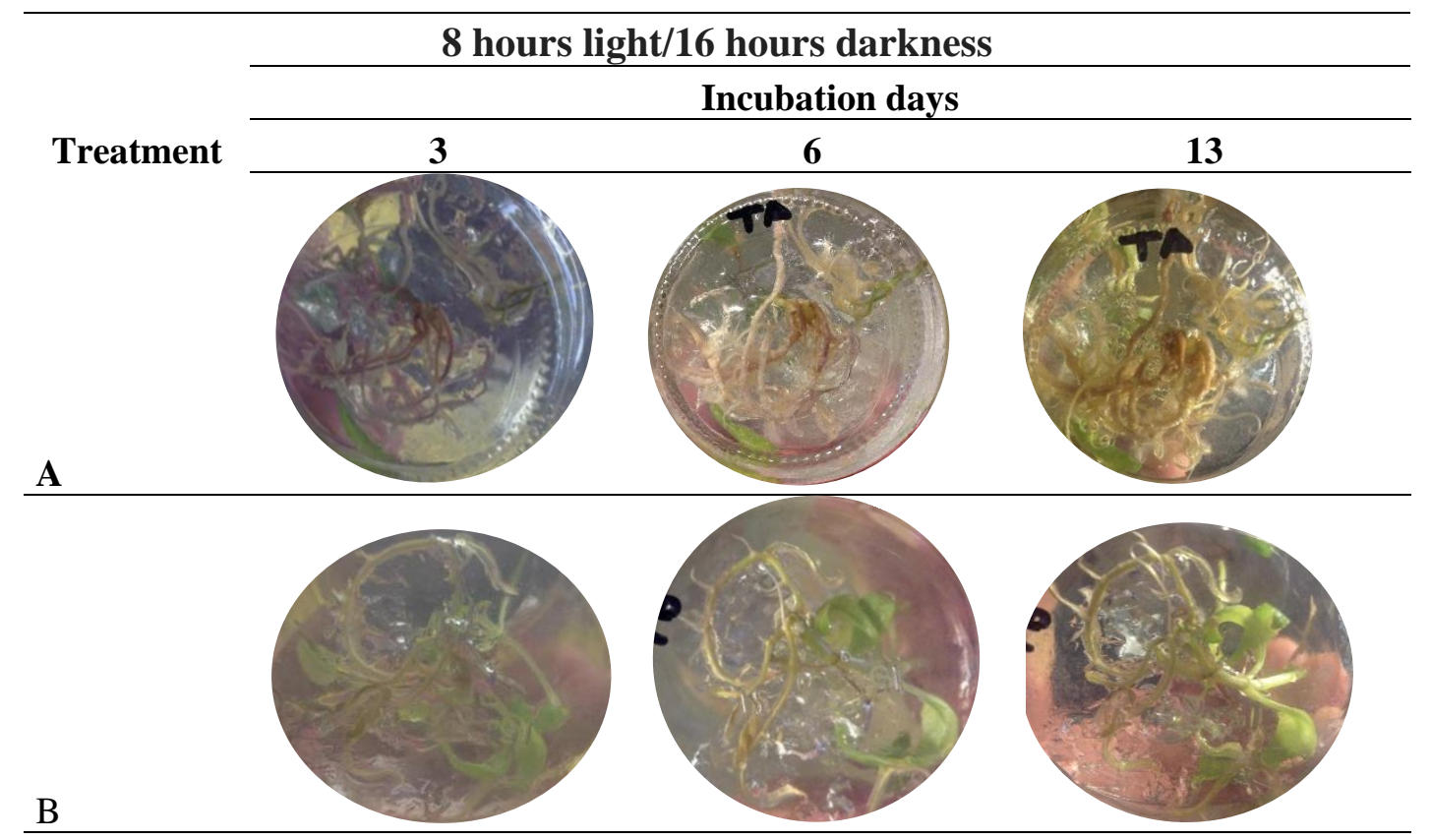

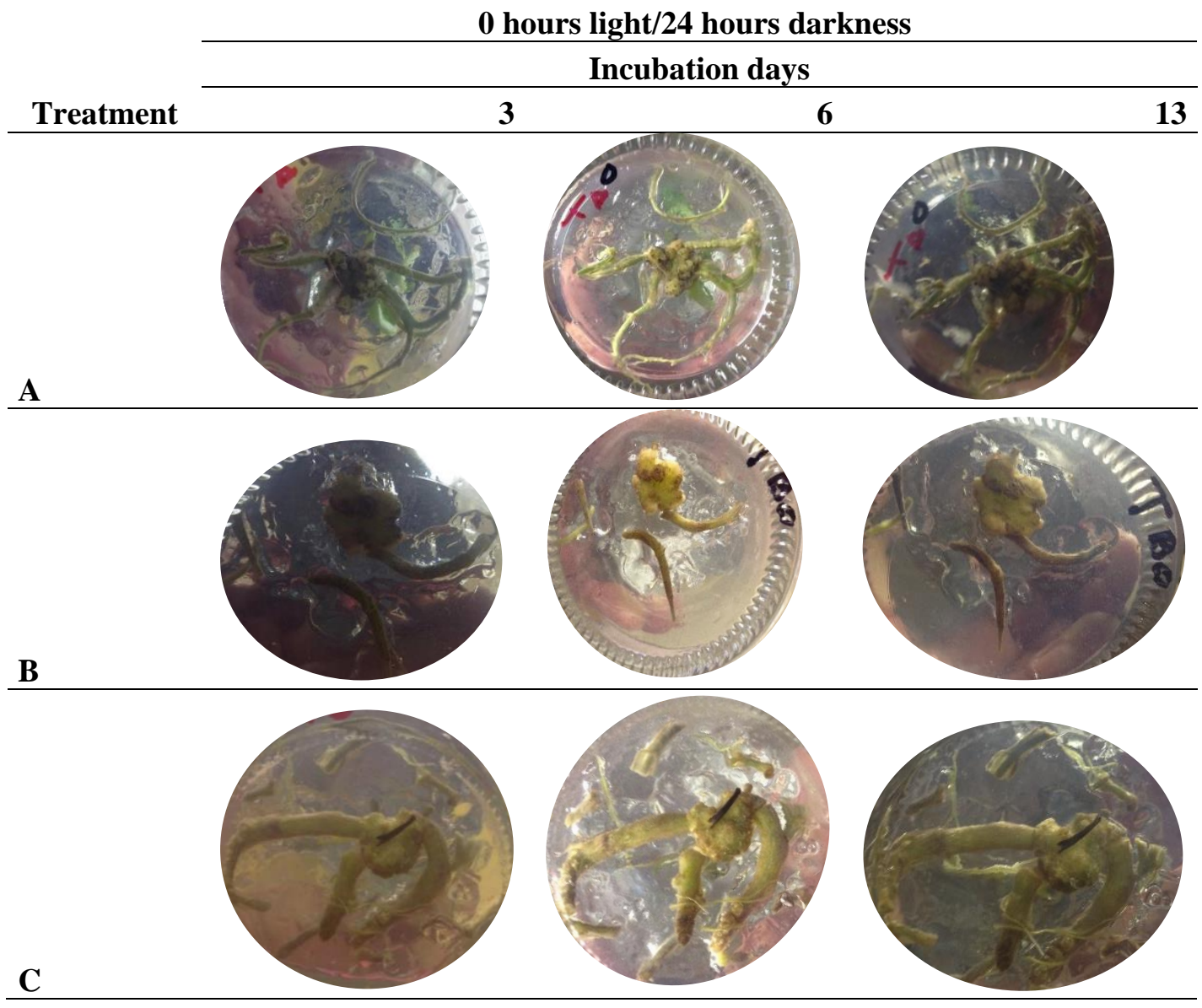


In relation to root cultures, for the three formulations used, new root growth was evident after 6 days of incubation, with more new roots being observed in medium $\mathrm{C}$ followed by medium A and medium B. With the passage of days, the treatment B showed thick roots and in greater quantity, in addition the explants continued green. For treatment $\mathrm{C}$, roots amber to brown were observed, as well as their explants (Figs. 5B and 5C). In treatment A resulted a low root proliferation (Fig. 5A).
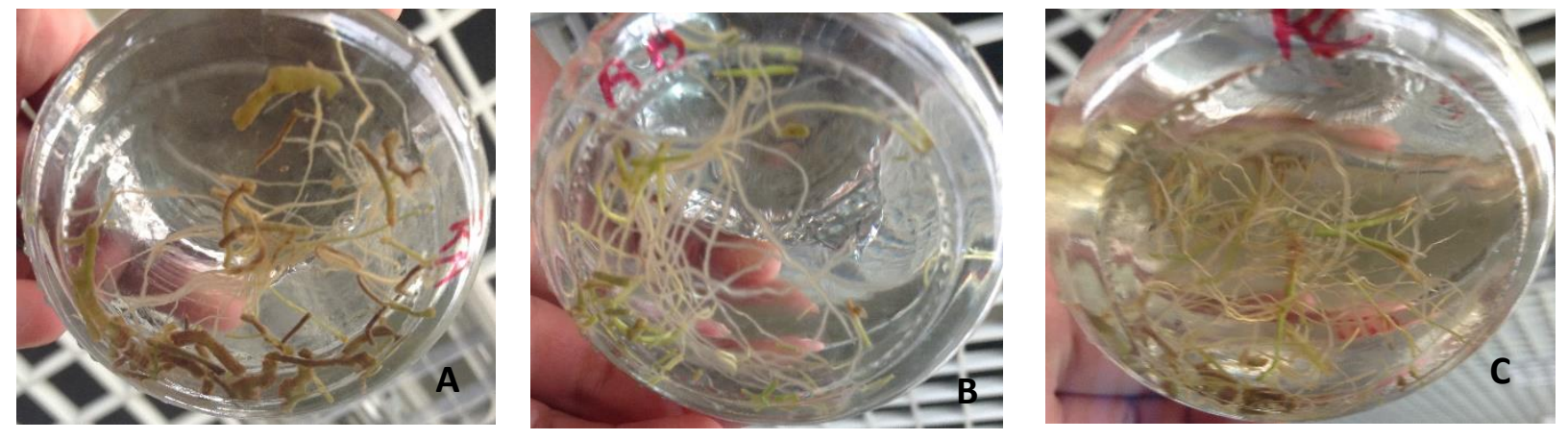

Fig. 5. Root cultures of $P 1$ after 28 days of incubation. A: RA treatment. B: treatment RB. C: RC treatment.

\section{DISCUSSION}

Five Dahlia sp. plant lines were propagated to have an efficient protocol and to be able to produce inulin in the future. Through the technique of plant tissue culture shoots, calli, cell and roots suspension were obtained by using multiple treatments with different combinations of plant growth regulators and environmental conditions. Shoots were obtained and consecutively the roots generation to regenerate Dahlia sp. complete plants in a short period not previously reported, since complete plants were obtained with P1 line in 7 days of incubation (Fig. 1). Al-Mizory (2013) obtained shoots of $4 \mathrm{~cm}$ long after 6 weeks of incubation and with BAP as a plant growth regulator. In this work, we obtained complete plants six times faster, with a lower cost, since plant growth regulators were not used and 1.7 times higher, ie, plants of $6.6 \mathrm{~cm}$ in height. The number of shoots per explant were 2, which corresponding to half of those reached by Al-Mizory (2013) but were obtained after 4 days of incubation with the fastest line. With our protocol it was possible to double the number of plants in 15 days by subculture of axillary buds from plants generated in vitro, in this way it is possible to compensate the limited number of shoots that were obtained. For the plants obtained in vitro of Dahlia sp. plant lines it was necessary to make a frequent subcultures since necrosis of apical leaves was common due to its union with culture vessel. De Klerk \& ter Brugge (2011) attributed this necrosis to deficiency in the translocation of the few assimilated nutrients in the cut zone in the semisolid cultures. 
Dahlia sp. tissues were susceptible to plant growth regulators and general manipulation, since oxidation of the explants (axillary buds and stems) was evidenced after 4 days of incubation. This effect was marked with the calli induction treatment using 2,4dichlorophenoxyacetic acid (2,4-D), which was discarded immediately becase it caused oxidation of the explants and did not promote the desired response. Mexican lines metabolize 2,4-D differently compared to species which it does not cause inhibition of expected response (Montague et al., 1991). On the other hand, there was cell lysis in rpm above 100 during callus suspension culture (Fig. 4) and oxidation of the same. This lysis effect appears to be due to large size of detached cells, in both cases $5.1 \mu \mathrm{m}$ (Fig. 4A) and $7.2 \mu \mathrm{m}$ (Fig. 4B). Thus, it was proposed the redesign of agitation conditions in this large plant cells that are susceptible to hydrodynamic stress (Chattopadhyay et al., 2002), which restricts the use of high agitation to ensure efficient mixing. The reduced time to get calli was also a constant in Dahlia lines (Fig. 2) and with reduction of phytagel concentration to $1 \mathrm{~g} / \mathrm{L}$, it was possible to counteract oxidation and promote cell proliferation in explants without the need of using antioxidants as did Ibrahim \& Daraj (2015). Also, it was not necessary to have embryonic plant tissues such as cotyledons and hypocotyls (Fatima et al., 2007) to achieve calli. This was advantageous since the seeds of the plant did not germinate because their lack viability (Mera Ovando \& Bye Boettler, 2006). The friability of the nodular callus obtained in suspension cultures with A2 and P1 was reduced. However, continuous subcultures (Brown, 1990) are expected to select cells that can establish cell suspensions (Fig. 3D). Establishing cell suspension cultures would give us the advantage of relatively easily scaling of biomass production and would enable the handling and extraction of desired component. On the other hand, it was necessary to obtain green calli from plant to avoid its oxidation and to maintain cell proliferation in suspension cultures. This contrasts with Ibrahim \& Daraj results (2015), since their greatest calli proliferation were white. In addition, green callus phenotype is necessary for indirect organogenesis (Ibrahim \& Daraj, 2015 and this work). Possibly the reason why plant cells are dependent on light is for stimulation of chlorophyll maturation (Salisbury \& Ross, 2008 Therefore it was concluded that chlorophyll plays an important role in cell division maintenance of dahlia and opens up a field of interest to be analyzed. Tuberization treatments were adapted of Solanum tuberosum for Dahlia sp. because until now there are no protocols for its tuberization. Dahlia roots thickening was required (Table 3) as it shows biochemical and physiological changes (Du et al., 2011). And unlike potato, the root is not modified as a spherical tuber, but as an elongated cylinder. In the in vitro cultures we observed that the Dahlia sp. roots formed nodules that did not always develop adventitious roots (Table 3). For this result the root cultures were made to allow the generation of these nodules. However, it was evident that such nodules were no formed (Fig. 5) and thickening was minimal. Thus, it seems necessary to used explants of larger roots or even the plant aerial part to establish the molecular signals involved in the tuberization metabolism. 
According to the results, our Dahlia sp. plant lines have a genetic variability that allowed them to adapt and respond to in vitro culture conditions tested in comparison with the cultivars used in other countries. This same genetic variability also allowed the exception of use of plant growth regulators for roots formation on the shoots previously obtained. Fatima et al. (2007), Ibrahim \& Daraj (2015) and Al-Mizory (2013) had to add to culture medium IBA at levels of 0.3 to $0.6 \mathrm{mg} / \mathrm{L}$ for root induction in shoots of the cultivars they worked. This results indicates that our country has a source of valuable germplasm, which makes possible its exploration and guarantee a probable success. The response time and the quality of the shoots, calli and roots that we obtained from Dalhia sp. show favorable experimental conditions for initiating experiments for inulin stimulation.

\section{ACKNOWLEDGEMENTS}

The authors thank Q.F.B. Karen Paola Mejía Márquez (UPIIZ-IPN) for providing us the Dahlia sp. plant lines.

\section{CONFLICT OF INTERESTS}

The authors have no conflict of interest to declare.

\section{REFERENCES}

Al-Mizory L. S. M. 2013. Effect of different concentration of cytokinins, carbon source and agar on in vitro propagation of Dahlia sp. through one single node. Journal of Life Sciences. 7(10): 1103-1112.

Anjum M.A. \& Trevor T.A. 1997. Induction of microtubers in vitro from stem segments of Solanum tuberosum L., S. commersonii Dun. and S. acaule Bitt. Scientia Horticulturae. 70: 231-235.

Arenas J.Y.R., Delgado-Martínez R., Morales-Rosales E.J., Laguna-Cerda A., Franco-Mora O. \& Urbina Sánchez E. 2011. Tuberous root yield of Dahlia variabilis Wild (Desf.) under different agronomic management practices. $\phi Y T O N$, Revista Internacional de Botánica Experimental. 80: 107-112.

Badui D. S. 2013. Química de los alimentos. 5ª ed. Pearson. México. pp 723.

Brown J.T. 1990. The initiation and maintenance of callus cultures. En: Methods in Molecular Biology, vol 6, Planf Cell and tissue Culture. Editado por Jeffrey W Pollard and John M Walker. The Humana Press. 57-63.

Chattopadhyay S., Farkya S., Srivastava A. K., \& Bisaria V. S. 2002. Bioprocess considerations for production of secondary metabolites by plant cell suspension cultures. Biotechnology and Bioprocess Engineering. 7: 138-149.

De Klerk G.-J. \& ter Brugge J. 2011. Micropropagation of Dahlia in static liquid medium using low-release tools of medium ingredients. Scientia Horticulturae. 127: 542-547. 
Du H., Ding M., Tang D. \& Huang D. Analysis of diffrential protein expresión during the early stage of in vitro tuberization in taro. Scientia Horticulturae. 129:904-909.

Fatima B., Usman M., Ashraf T., Waseem R. \& Ali M.A. 2007. In vitro shoot regeneration from cotyledon and hypocotyl explants of Dahlia cultivars. Pakistan Journal of Agricultural Sciences. 44(2):312-316.

Hernández Pérez, F. y Mejia Muñoz, José M. 1994. Micropropagación de Dahlia. Revista Chapingo. Serie Horticultura. 1(1): 63-66.

Ibrahim M.A. \& Daraj I.A.2015. Micro propagation of dahlia plants (Dahlia variabilis). Direct and indirect organogenesis techniques. AAB Bioflux. 7(1):28-35.

Mera Ovando L.M. \& Bye Boettler R. 2006. The Dahlia, 100\% Mexican beauty. Revista Digital Universitaria. 7 (1): 1-11.

Montague M. J., Enns R. K., Siegel N. R., \& Jaworski E. G. 1981. A comparison of 2,4Dichlorophenoxyacetic acid metabolism in cultured soybean cells and in embryogenic carrot cells. Plant Physiology. 67: 603-607.

Salisbury F.B. \& Ross C.W. 1992. Plant physiology (4th ed). Wadsworth Pub. Co, Belmont, Calif.

Skoog F., Strong F.M. \& Miller C.O. 1965. Cytokinins. Science. 148:532-533. 